\title{
Urban regeneration of historic towns: regeneration strategies for Pauni, India
}

\author{
P. Parlewar \& Y. Fukukawa \\ School of Architecture and Planning, Chiba University, Japan
}

\begin{abstract}
The urban regeneration of historic towns is a process of inducing life into decaying assets and developing future potential. These assets and potentials may consist of built heritage, traditional industries or cultural resources. The research is a study of an historic town in central India called Pauni which is famous for its historic buildings and traditional economic industry. However, at present these assets are degenerating due to industrialization. Between the $14^{\text {th }}$ and $16^{\text {th }}$ centuries, the town achieved prosperity because of location, linkages, political patronage and existing economic skills. Later the town could not achieve growth due to a lack of economic potential and out migration of skilled workers. Also the inadequate development polices affected the town's growth and with the passage of time it retained the historic settlement pattern. The town today has a strong potential for tourism as there are numerous historic buildings. The town economy is dominated by household industry of skilled master craftsmen involved in producing fabric from silk and cotton. But at present, this traditional heritage and the economic potential of the town are struggling to survive. The research looks into the town's assets and potentials that could be a base for development and sustainability.

Keywords: historic towns, urban regeneration, urban conservation, urban planning, built heritages, household industry, handloom cottage industry, sustainability, weavers, tourism.
\end{abstract}

\section{Introduction}

The settlement patterns in India are an overlay of civilizations belonging to different periods in the history of Hindu, Buddhist, Mughals and British rule. This overlaid pattern has developed urban forms that reflect the diversity in social and cultural needs of the inhabitants. The architecture of these urban forms 
has interesting elements like forts, palaces, traditional houses and religious buildings. Many cities in India have these overlaid patterns of historic architecture but, in the process of urbanization, they are struggling to survive. In this process, the industrialization of major urban centres has forced the rural population to migrate to urban areas in search of better economic opportunities, thereby reducing rural growth. The research is study of a rural town, Pauni, which has historic settlement pattern of various periods in history. Due to a lack of physical and economical development, the town retains its historic architecture and traditional economic skills but is struggling to sustain itself the in modern economy. This research tries to study the problems and prospects for the potential of historic buildings and traditional economic activity for the regeneration of the town.

\section{Pauni: the town profile}

Pauni, a walled city with a population of 21,857 is located in central India. The total area of the town is about 294.12 hectares and is located about $85 \mathrm{~km}$ from a major city Nagpur (Figure 1). Out of various overlaid patterns of human settlements, the first settlement in Pauni dates back to 100 B.C. when Buddhism was flourishing in India. Later in the $2^{\text {nd }}$ century A.D. the town was under Hindu rule. The dominance of rule continued until the $12^{\text {th }}$ century. After these dates the town was invaded by Mughals. Again in the $15^{\text {th }}$ and $16^{\text {th }}$ centuries the town came under Hindu rule. This period is generally referred as medieval period of Indian history. The town became part of British rule when the East India Company took Nagpur and the surrounding region in 1817.
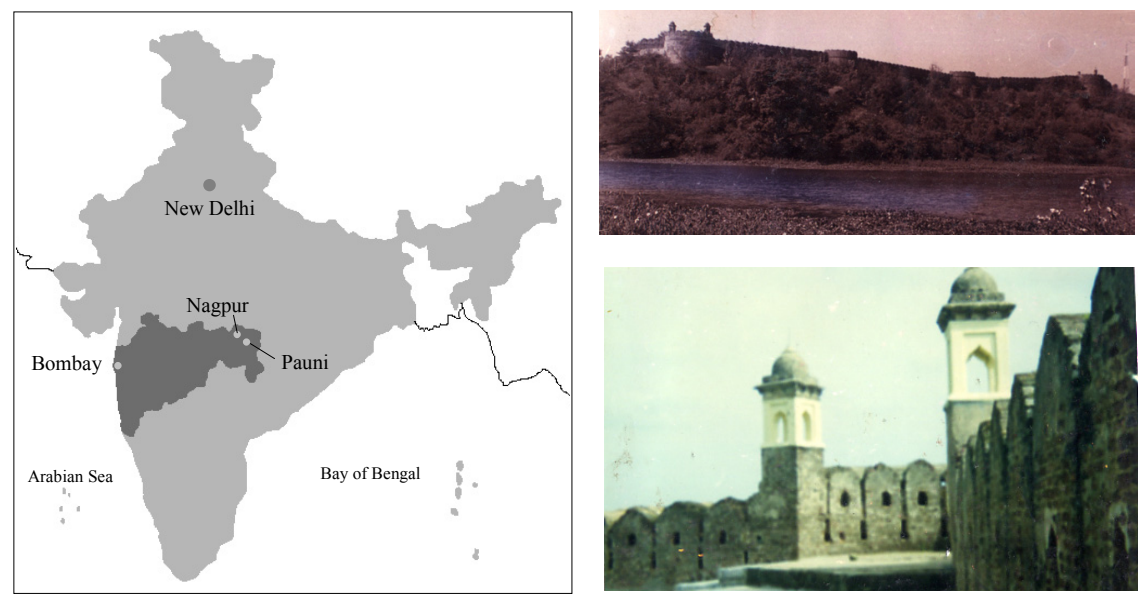

Figure 1: Map of India, street view of town and Pauni fort wall.

\subsection{The prosperity and decline}

Once, during prosperity, the town increased its population to 60,000 persons but the political instability and industrialization lead to a decline of historic assets and traditional economic industry. It was the period between the $12^{\text {th }}$ to $17^{\text {th }}$ 
centuries when there was political and administrative stability in the town. The traditional economic activities flourished because of this stability. The town gained its glory by becoming a major exporter for silk and cotton fabric as cocoons and cotton were grown in abundance in the surrounding region. The climate, location and political patronage lead to flourishing trade and commerce. The navigable river gave accessibility to export its product in the region and other parts of the nation.

During 1750-1800 political patronage was lost. The administrative instability and industrialization of many cities in the surrounding area reduced the demand for silk. Modernization invaded with the influence of the western countries and reduced the demand for fabric. Hence many skilled workers migrated in search of better opportunities.

\subsection{The Unique feature of Pauni}

The town is unique and famous in the region for its history, culture and tradition. It is well known in the surrounding area as the 'Town of Temples' as there are more than 150 temples. Hence many festivals are celebrated in the town, attracting people from the surrounding area. In the past the town was famous for its silk industry and skilled master craftsmanship of the weaving community. During industrialization, power looms replaced the hand looms and reduced the importance of master craftsmanship. But many of the skilled master craftsmen still exist today and they export products to different parts of country. Apart from this, various political patronages left numerous assets of heritage sites. The heritage sites of the town include temples, a fort, an archaeological excavation site, step wells, caves, Buddhist stupas and traditional style residences.

\subsection{The physical environment of the town}

The town environment has a picturesque setting of an earthen fortification with a moat. The natural scenic places, built heritage and river front together give a unique physical setting to the town. Today, about $51.10 \%$ of the area within the municipal limits is developed and $48.10 \%$ is undeveloped. The physical growth is stagnant as there is no economic potential. Also, because of the fortification, physical growth has been restricted. But in the past few years certain parts of town have grown outside the fortification forming a major activity node near historic entrance gate (Figures 2 and 3).

Even though the town has many assets and much potential there have been quit a few physical interventions. The inadequacy of this intervention has forced the town to survive on a bare minimum of infrastructure, below reasonable living standards. The general infrastructure of the town shows poor conditions of roads, lack of potable water supply and sanitation services. This has caused unhealthy living conditions in the town.

\section{The heritage sites}

Most of the heritage sites of Pauni are from the medieval period. The architecture of these sites includes use of local sand stone and wood with ancient construction technologies. Many accidental discoveries have found relics belonging to 
$1^{\text {st }}$ century B.C. and $12^{\text {th }}$ century A.D. [4]. The frequent occurrence of such discoveries has shown that there may be undiscovered layers of historic towns beneath.
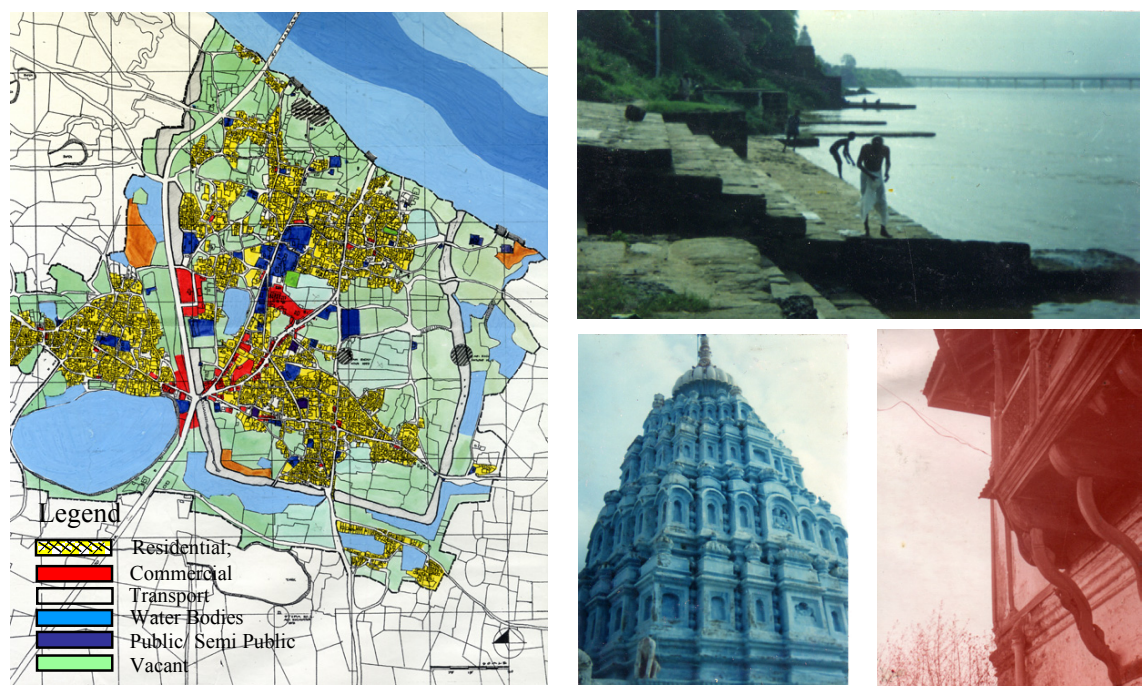

Figure 2: Landuse Map of Pauni, view of the riverfront, temple and residential architecture.

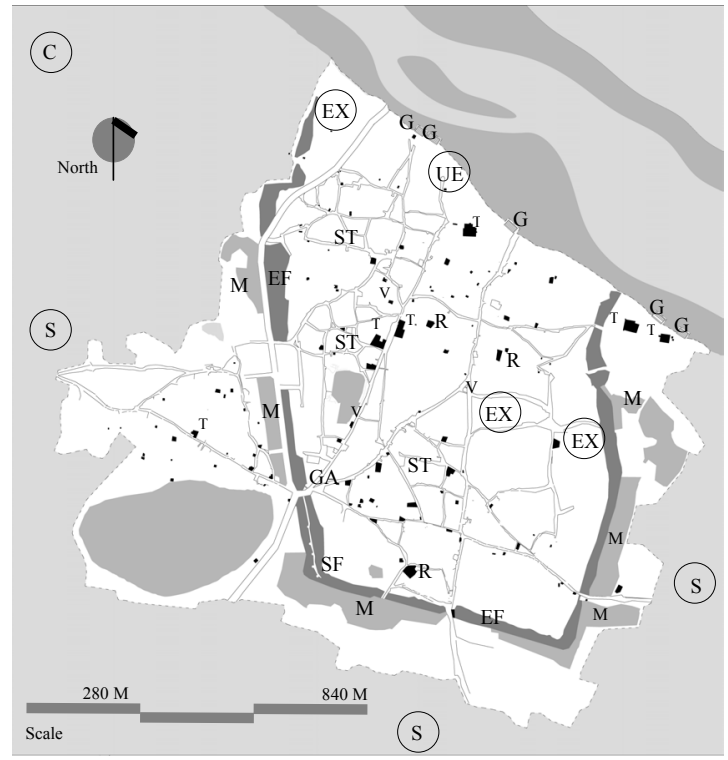

\section{LEGEND}

S - Excavated Buddhist Stupas

G - Ghats

ST - Step wells

UE - Unexcavated castle

R - Traditional Residences

M - Historic Moat

$\mathrm{T}$ - Large Temples

- - Small and Medium Temples

V - Votive Pillars

EF - Earthen Fortification

C - Historic Caves

EX - Archaeological Excavation Sites

SF - Stone Fort Wall

GA - Historic Gate

Figure 3: Map showing various heritage sites in Pauni. 
In the present physical form of the settlement, numerous temples are scattered around. The architecture of these is influenced by ancient Hindu temple architecture from central and southern India with decorative ornamentations and interesting spatial forms. Many of these temples are in private ownership. So they are well maintained and protected under the Archaeological Survey of India Act. Various excavations have explored the possibility that there might have been a Buddhist settlement beneath or around the town. But the exact traces of this settlement have not been found. The excavation of 3 Stupas has explored numerous relics. These three excavation sites dates back to the $1^{\text {st }}$ century B.C. and $2^{\text {nd }}$ century A.D. [1].

Within the walled city there are three step wells constructed out of sand stone. A step well in Indian architecture is an interesting architectural element that have stepped platforms with elaborate decorations, acting as a communal space for the community. In Indian cites, connections of river and city form an important transitional space through architecture elements called Ghats. In Pauni about 5 Ghats connect rivers making a picturesque riverfront. Such a historic towns have a unique house pattern called Wada. A Wada as a house pattern was evolved during the medieval period and have two or more courtyards and most of the activities are concentrated around a central courtyard. The architecture of Wada consists of ornate pillars, doors, windows and motifs made out of wood by skilled craftsmen. Pauni has many such Wada in private ownership. Apart from these, there are many other heritages like ancient caves, fort walls, votive pillars and an historic moat that gives historic ambience to the whole walled city.

The Archaeological Survey of India and The Indian National Thrust for Art and Cultural Heritage manage most of the heritage. Although some of the heritage sites are protected under law but many of them need urgent attention for preservation.

\subsection{The problems and potential of built heritage}

All of these built heritages in Pauni show strong potential to conserve because it's unique architecture of ancient technology, use of materials, artistic values and historic significance. The important reasons to neglect the potential of these assets are inadequate administrative setup, unavailable finances and ownerships with different organizations. But despite this, the community has shown a strong will to conserve and many of the heritage sites in private ownership are well maintained. Interestingly, local citizens have taken the initiative by forming a 'Community Conservation Unit' that has increased the attention of various authorities in the region.

\section{The traditional economic industry}

\subsection{Handloom cottage industry: a perspective}

At present there are many economic activities in Pauni but the dominant part of economic activity is shared by household industry, i.e. handloom cottage industry. Also agriculture is a main source of income for many inhabitants due to the lack of manufacturing industries. Since other economic activities in town are 
self sustaining, the research focuses on handloom cottage industry as it is struggling to sustain itself.

Once, Pauni and the surrounding regions were the largest producers of cotton in India. As cotton was grown in abundance, the handloom cottage industry flourished in Pauni. Some historic traces have shown that during its peak period there were about 25,000 people involved in this industry. The decline of the industry continued with industrialization and in 1955 there were about 13,854 peoples involved in this occupation [3]. Unfortunately, after this the decline was much sharper and today there are about 1296 persons involved in this occupation. Also, there are many more weavers who own looms but cannot continue this occupation as the demand of products is reduced.

\subsection{Importance of weaving in Pauni}

From historic times the handloom cottage industry has retained its significance because of the production of high and medium count artistic fabrics. The fabrics produced from silk and cotton have been the important products of the town. The unique feature of weaving in Pauni is its artistic design of master craftsmanship which is produced on high count fabric with use of natural colours.

\subsection{The prosperity and decline}

The abundance of cotton as raw material, favourable climate and availability of water were the main reasons the weaving industry in Pauni flourished. During the political patronage of Hindu and Mughal rulers, the industry was uplifted to boost the economy of the town. Particularly during the Mughal rule, the industry prospered by using gold and silver in the fabric. The uniqueness of the fabric and available skills of spinning and weaving of skilled master craftsmen were the main reason for the growth of this industry. In its peak period, the town had a good export trade in regional and national markets. At the same time the coarse fabric was easily disposed off in the local market.

The end of political patronage and unstable administration precipitated the decline of the town. Famine occurred during various periods and also increased the costs of living, further reducing the demand of fabric. This reduced the wages of weaving and led to a high cost of production. Moreover, an invasion of new technology and demand for machine made fabric lead to the decline of the industry. As a result of the decline, weavers began to work as ordinary labourers or in agriculture. Hence the independent weaving system collapsed and the income of a weaver reduced to Rs. $300-350$ /- (\$ 6-7) per month.

\subsection{The weaving community: physical and socio-economic}

Although weaving was once prestigious work in Pauni, today, because of economic disabilities, most of the weavers live in poor physical conditions. The houses of weavers are predominantly one room or two rooms. The loom and weaver's family coexist in a single room. In studies it was found that $55 \%$ don't 
have access to potable water supply and about $37 \%$ don't have their own sanitary facilities.

The dominant age group of weavers undertaking this occupation is above 40 with a marginalised participation from the younger generation as there is no future economic prospect in this occupation. Generally, the weavers in Pauni fall into one of three categories: a) weavers who are involved in producing silk fabric, b) weavers who are involved in producing high count cotton fabric and c) weavers who produce coarse cotton fabric. The weavers in first two categories fetch good money as there is available demand but those who are involved in producing coarse fabric earns below Rs. 350 /- (\$ 7) per month despite the skills of master craftsmanship. Many weavers are in debt and borrow money from friends and family. From the analysis it was observed that $60 \%$ have taken loans for buying raw materials. Interestingly, in many case studies it was found that most of the weavers have extraordinary skills and strong willingness to conserve this occupation.

\subsection{The weaving cycle and process: past and present}

In the past, an independent weaving system was dominant in Pauni. During this time the factory system and master weaver system used to share certain parts of production. In 1940, about $80 \%$ of weavers were working as independent weavers. In the independent weaving system a weaver would undertake most of the activities like the purchase of raw materials, production and marketing. The advantage of this system was that weavers were able to set their own prices and had access to a free market. In this system considerable profit was gained by the weaver. Also the factory system was stable and profitable because of a high production cycle.

At present the independent weaver system has collapsed and cooperatives provide raw materials to weavers. The wavers then have to produce and supply the product to the cooperatives. In return the cooperative sells the product in regional markets. The advantage of this system is that there is a continuous supply of raw materials. But the disadvantage of this system is that the weaver has lost the access to a free market and total gains to the weaver are marginalized.

To understand the production cycle, the process of production was analyzed and it was found that the silk fabric weavers are highly productive but the cotton fabric weavers have to undertake a complicated process. The initial part of the cotton fabric production process is time consuming and needs large preparation and storage space. In the preparation process the weavers have to employee 3 to 4 persons and this increases the cost of production. The appliances and techniques used by weavers have also had an effect on the production process. The appliances used by many of the weavers are outdated and the poor weaver could not afford to repair or replace it. Also the lengthy process of preparation, time consumption and high labour intensiveness has reduced the productivity and hence the demand for the fabrics. 

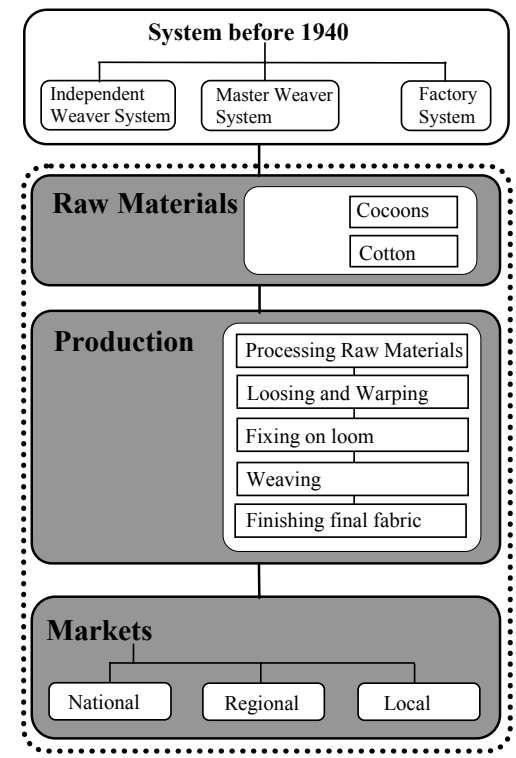

Past System

Part in which weaver is involved
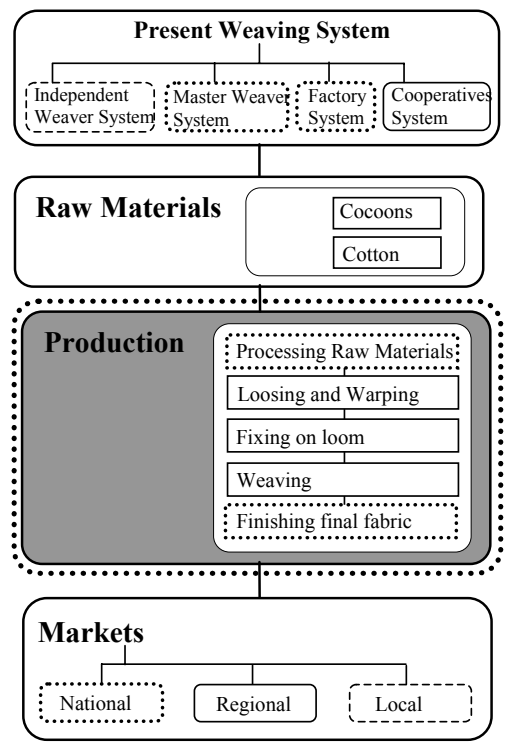

Present System

Part of process that no more exists
- - - Part of process that exists to certain level

Figure 4: $\quad$ The process of weaving - past and present.

\begin{tabular}{|c|c|c|c|c|c|c|c|}
\hline Group & $\begin{array}{l}\text { Length } \\
\text { of fabric }\end{array}$ & $\begin{array}{l}\text { Days for } \\
\text { Preparation }\end{array}$ & $\begin{array}{l}\text { Days for } \\
\text { weaving }\end{array}$ & $\begin{array}{l}\text { Persons } \\
\text { involved }\end{array}$ & $\begin{array}{l}\text { Cost of raw } \\
\text { materials }\end{array}$ & Wages & Price \\
\hline $\begin{array}{l}\text { 1.Cocoon } \\
\text { fabric }\end{array}$ & $5.03 \mathrm{~m}$ & 1 Days & 15 Days & 3 Persons & $\begin{array}{l}@ 900 \mathrm{Rs} . \\
(\$ 2.6)\end{array}$ & $\begin{array}{l}350 \text { Rs. } \\
(\$ 7.92)\end{array}$ & $\begin{array}{l}2100 \text { Rs. } \\
\text { (\$47.55) }\end{array}$ \\
\hline $\begin{array}{l}\text { 2.High } \\
\text { count cotton } \\
\text { fabric }\end{array}$ & $8.23 \mathrm{~m}$ & 14 Days & 4.5 Days & 4 Persons & $\begin{array}{l}@ 115 \text { Rs. } \\
(\$ 2.6)\end{array}$ & $\begin{array}{l}138 \text { Rs. } \\
\text { (\$ 3.12) }\end{array}$ & $\begin{array}{l}238 \text { Rs. } \\
\text { (\$ 5.39) }\end{array}$ \\
\hline $\begin{array}{l}\text { 3.Low count } \\
\text { cotton fabric }\end{array}$ & $5.03 \mathrm{~m}$ & 14 Days & 2.5 days & 2 Persons & $\begin{array}{l}@ 120 \text { Rs. } \\
(\$ 2.72)\end{array}$ & $\begin{array}{l}35 \text { Rs. } \\
\text { (\$ 0.79) }\end{array}$ & $\begin{array}{l}175 \mathrm{Rs} . \\
(\$ 3.96)\end{array}$ \\
\hline
\end{tabular}

Figure 5: Cost of products, wages and time consumed.

\section{Role of authorities and regeneration efforts}

The Town and Country Planning Department (TCPO) and Municipal Corporation look after the urban development in Pauni. The role of the TCPO is plan formulation and financing and the Municipal Corporation look after the implementation of plan. Various other responsibilities of conservation, pilgrimage, tourism and economic activities are shared by many different authorities. This has increased overlapping responsibilities and difficulties in coordination, there by reducing the efficiency in development.

Efforts to regenerate Pauni include the planning activities by various governmental and non-governmental organizations. The regional development plan has emphasized development control and conservation of historic 
monuments in the region. The Pauni Development Plan, 1991 has planned for manufacturing industries outside the town [2]. Many of the infrastructural development proposed in the plan are not implemented because of a lack of finances with the local authorities. In this present regeneration effort, the inner voice of the settlement is not reflected as there is no concern for existing assets and potentials. Various non-governmental organizations (NGO) have made some efforts to restore and document the built heritage of the town. The efforts have also been made for publication and to achieve the governmental support to conserve the traditional assets of the town, but these efforts have remained partial for regeneration.

\section{Problems and need for sustainability}

The historic ambience of Pauni no longer exists. Most of the efforts have not given sufficient base to uplift the town. The urban development authority and other organizations need financial support and a better administrative setup. The decaying heritage and traditional economic activities have raised the issue of sustainability of the town.

The physical and economic activity problems of Pauni are as follows.

a. The heritage sites and natural scenic places are gradually degrading and some of them need immediate protection. Important heritage sites do not have the basic infrastructural services like paved roads, electricity and drainage, which is decaying them further. Also, in many parts of the town there is poor physical and social infrastructure that has affected the health and hygiene of the inhabitants.

b. The dominant part of the economy is shared by the handloom cottage industry, which is struggling to sustain itself because of reduced demand.

c. The production process has been labour intensive, time consuming and expensive with outdated production technology. Necessary efforts are needed to facilitated training, education and finances to improve the productivity.

d. The poor physical living environment, lack of space and infrastructure has reduced the efficiency of the weavers.

The town has many environmental and traditional assets that could be recycled for present needs. Recycling these assets could uplift rural poverty with existing skills for the sustainability of the town. Moreover the existing economic activity still has demand and shows potential for sustainability.

\section{The regeneration approach for Pauni}

From the various findings an approach was suggested that could promote the regeneration of Pauni by conserving existing resources of traditional heritages and economic activity. Although the historic assets only could not be a base for development in modern economy, it was found that the town has a strong potential for regional tourism. The regeneration strategies for Pauni were conceptualized for tapping regional tourism, integrated conservation with development and recycling existing economic skills. The past cycle of the independent weaving system could be revived by creating new markets through 
standardization and diversification of existing products. A free market could be created by developing common places for work, sale, exhibition and training at regional and local level. The heritage sites could be an important asset for tourism-based development of the town. This could be restored and reinterpreted through community participation and partnerships with local citizens, universities, NGOs and local government. Many of the heritages were suggested for adaptive and active reuse like museums, shops, etc. Restructuring the existing organization and integration role of local authorities in conservation could be a possible way to implement such strategies for developing tourism in Pauni.

\section{Conclusions}

The urban regeneration of historic town Pauni, heritage sites and traditional economic activity could be assets to uplift the economy. Recycling existing assets and tourism based development could give an impetus for improving the infrastructure and sustainability of the town. In the suggested approach the regeneration of the tourism industry could be tapped along with gradual development of manufacturing industries.

In India there exist many such towns that have immense assets of heritage sites and traditional economic skills. Out of many such historic towns in India, the settlement pattern in Pauni is similar to towns like Chanderi, Kachipurum and Bhuranpur. The research is an approach to understand the regeneration of one such historic town in India where traditional assets could be a base for tourism. This research is also part of ongoing further research on urban regeneration of historic towns in Japan like Nagahama, Sawara and Kawagoe. Although the economic activity structure, settlement pattern and planning system in Japan are completely different from India, innovative approaches have been used in the urban regeneration of these historic towns. The city of Nagahama in central Japan underwent a successful regeneration through introducing the 'glass industry' to promote integrated conservation and tourism in the town.

\section{Acknowledgement}

I will like to acknowledge Prof. (Mrs) Veena Garella, Professor, School of Planning and Architecture, New Delhi for her guidance on this research in India.

\section{References}

[1] Archaeological Survey of India, Pauni Excavation Report, ASI publications, New Delhi, 1991.

[2] Town and Country Planning Department, Pauni Development Plan, Bhandara District, Maharashtra State, India., 1973 and 1996.

[3] Nanekar K.R., Handloom Industry in Madhya Pradesh, India., Nagpur University Press, Nagpur, India, 1968.

[4] Meshram P., Pauni - A Important Hinayana Buddhist Center, Department of Ancient Indian History Culture and Archaeology, Nagpur University, 1994. 